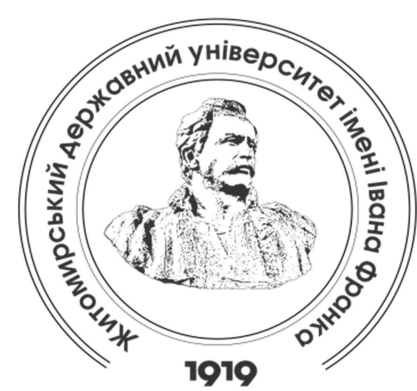

Zhytomyr Ivan Franko State University Journal. Pedagogical Sciences. Vol. 2 (101)

Вісник Житомирського державного університету імені Івана Франка. Педагогічні науки. Вип. 2 (101)

\author{
UDC $167+376+37.037$ \\ DOI 10.35433/pedagogy.2(101).2020.122-132
}

\title{
APPLICATION OF PHYSICAL AND HEALTH PROGRAM IN CHILDREN WITH COMPLEX DEVELOPMENTAL DISORDERS FOR CORRECTION OF PHYSICAL DEVELOPMENT AND PSYCHO-EMOTIONAL STATE
}

\begin{abstract}
N. P. Leshchii ${ }^{*}$
The article deals with the issues of using means of physical and health program for correction of physical development and psycho-emotional condition of primary school age children with complex developmental disorders. One of the conditions for successful rehabilitation and further socialization of a child with special educational needs is physical culture. The purpose of the study is to substantiate the physical culture and health program for children of primary school age with complex developmental disorders and experimental study of its effectiveness for correction of physical development and psycho-emotional state of children. To achieve this goal, a set of interrelated methods was used: methods of theoretical level of research; methods of empirical level (pedagogical observation, pedagogical experiment to determine the effectiveness of the developed physical and health program for children with complex developmental disorders); methods of mathematical statistics. The study involved 100 children of primary school age with complex developmental disorders, including 53 girls and 47 boys, who were randomly divided into 2 groups - experimental and control. Health and fitness program for children with complex developmental disorders was developed that included a rational combination of exercises of different directions; adherence to their optimal intensity and duration of performance in accordance with the individual characteristics of the child with complex developmental disorders; the starting position; comorbidities and the factor structure of the overall level of physical health of children. It has been found that that girls and boys with complex developmental disorders during the pedagogical study probably improved indicators of physical development and psycho-emotional state.
\end{abstract}

\footnotetext{
${ }^{*}$ Candidate of Pedagogical Sciences (PhD in Pedagogy), Associate Professor (South Ukrainian National Pedagogical University named after K.D. Ushynsky, Odesa) lleschiy@ukr.net
} ORCID: 0000-0002-8843-7156 
Key words: physical development; psycho-emotional state; physical culture and health program; educational and rehabilitation center; children with complex developmental disorders, well-being, activity, mood.

\section{ЗАСТОСУВАННЯ ФІЗКУАЬТУРНО-ОЗДОРОВЧОЇ ПРОГРАМИ У ДІТЕЙ ЗІ СКААДНИМИ ПОРУШЕННЯМИ РОЗВИТКУ ДАЯ КОРЕКЦІЇ ФІЗИЧНОГО РОЗВИТКУ ТА ПСИХОЕМОЦІЙНОГО СТАНУ}

\section{Н. П. Мещій}

Стаття присвячена проблемі застосування засобів фізкультурно-оздоровчої програми для корекцї фрізичного розвитку та психоемоиійного стану дітей молодшого шкільного віку зі складними порушеннями розвитку. Однією із умов успішної реабілітації та подальшоі соиіалізації дитини з особливими освітніми потребами є використання оздоровчого та реабілітаційного потениіалу засобів фрізичної культури. Мета роботи полягае $в$ обтрунтуванні фрізкультурно-оздоровчої програми у дітей молодшого шкільного віку зі складними порушеннями розвитку та експериментальному вивченні ї̈ ефективності шодо поліпшення фізичного розвитку та психоемоиійного стану школярів. У ході дослідження було використано наступні методи: методи теоретичного рівня дослідження; методи емпіричного рівня (педагогічне спостереження, педагогічний експеримент для визначення ефективності розробленої фрізкультурно-оздоровчої програми з дітьми зі складними порушеннями розвитку); методи математичної статистики. В дослідженні приймало участь 100 дітей молодшого шкільного віку зі складними порушеннями розвитку, з них 53 дівчинки та 47 хлопчиків, які методом випадкової вибірки були розподілені на 2 групи експериментальну та контрольну. Розроблено фрізкультурно-оздоровчу програму для дітей зі складними порушеннями розвитку, шо включала ращіональне поєднання вправ різного спрямування; дотримання оптимальної їх інтенсивності та тривалості виконання відповідно до індивідуальних особливостей дитини зі складними порушеннями розвитку; вихідного положення; супутніх захворювань та фракторної структури загального рівня фізичного здоров'я молодших школярів. Проведене дослідження свідчить про те, шио у дівчаток $i$ хлопчиків зі складними порушеннями розвитку упродовж педагогічного дослідження вірогідно поліпшилися показники фізичного розвитку та психоемоиійного стану.

Ключові слова: фрізичний розвиток; психоемоиійний стан; фізкультурно-оздоровча програма; освітнъо-реабілітаційний иентр; діти зі складними порушеннями розвитку; самопочуття, активність, настрій.

Introduction of the issue. One of the conditions for successful rehabilitation and further socialization of a child with disabilities is using of health and rehabilitation potential of physical culture. It is a powerful tool for developing children's skills, stimulates cognitive activity that gives practical experience and communication for child and might be an integral part of psychological rehabilitation $[2 ; 6 ; 11]$.

A significant role in this process belongs to the organization of complex physical culture and health work. The structure of the educational and rehabilitation center allows to consolidate the work of specialists of different specialties to achieve a common goal and implement the tasks of physical culture and health work, as well as to include physical culture and health activities in various parts of the rehabilitation process $[7 ; 8]$.

Current state of the issue. Leading researchers have revealed the peculiarities of education and physical education of children with psychophysical development disorders: visual impairments [4; 10]; hearing [9]; musculoskeletal system [3]; mental development [1] complex developmental disorders $[2 ; 5]$. It was found that despite a significant number of studies on various aspects of physical education 
of children with various disabilities, research on the organization of comprehensive physical culture and health work with children with complex developmental disorders in educational and rehabilitation centers are missing.

Outline of the unresolved issues brought up in the article. Thus, the theoretical analysis of scientific works allows us to state that the problem of physical culture and health work of children with complex developmental disorders is almost unresolved, which is hindered by a number of contradictions:

- between the increase in the number of children with complex developmental disorders and the lack of scientifically justified technology of physical culture and health work in the educational and rehabilitation center;

- between the need to involve parents of children with complex developmental disabilities in the educational and rehabilitation process and the lack of established cooperation with them;

- between the theoretical recognition of the need for consolidated participation of specialists of different specialties for the implementation of the tasks of physical culture and health work and its practical implementation;

- between the variability of manifestations of psychophysical and functional disorders in children with complex developmental disorders and the need to create individual fitness programs;

- between the need to increase the efficiency of physical culture and health work in children with complex developmental disorders and the lack of reasonable technology for this process.

Thus, there is an urgent scientific and applied problem of developing a physical culture and health program with children with complex developmental disorders in the educational and rehabilitation center, which has significant practical and social significance for maintaining the health of children.
Aim of research. The purpose of the study is to substantiate the physical culture and health program for children of primary school age with complex developmental disorders and experimental study of its effectiveness for correction of physical development and psycho-emotional state of children.

Research methods. To achieve the goal, a set of interrelated methods was used: methods of theoretical level of research; methods of empirical level (pedagogical observation, pedagogical experiment to determine the effectiveness of the developed physical and health program for children with complex developmental disorders); methods of mathematical statistics.

To assess the psycho-emotional state of children with complex developmental disorders before and after the application of physical and health program we used the questionnaire of well-being, activity and mood. The questionnaire consists of 30 pairs of opposite characteristics, according to which the recipient was asked to assess their condition. Each pair has a scale on which the child indicates the severity of a characteristic of his condition. Obtained points were grouped according to the key into three categories (well-being, activity, mood).

The average score on a scale from 1 to 4 indicated a low level of assessment of the child's condition; from 4 to 5 points the minimum allowable, sufficient level of assessment of the child's condition; from 5 to 5.5 - the optimal level of assessment of the child's condition; from 5.5 to 6 - a high level of assessment of the child's condition; from 6 to 7 - a very high level of assessment of the child's condition.

Body length was measured using Martin anthropometry with an accuracy of $0.5 \mathrm{~cm}$. Body weight was determined using medical scales with an accuracy of $100 \mathrm{~g}$. The circumference of the thorax was measured with a centimeter tape, which ran in front of the boys - on the lower edge of the nipple circles, and in girls - under the breasts at the level of 
the nipples and behind at the lower corners of the shoulder blades. Measurements were performed in a standing position, arms lowered along the torso. The study involved 100 children of primary school age with complex developmental disorders, including 53 girls and 47 boys, who were randomly divided into 2 groups experimental (EG) and control (CG).

To achieve current goal, indicators of physical development (height, weight, chest circumference) and a survey by the questionnaire of well-being, activity and mood were used to determine physical and the psycho-emotional state of children with complex developmental disorders.

Results and discussion. At the formative stage of the experiment, the children of the experimental group tested the physical training and health program, which included a rational combination of exercises of different directions; observance of their optimum intensity and duration of performance according to individual features of the child with difficult disturbances of development; starting position; comorbidities and factor structure of the general level of physical health of junior schoolchildren; children of the control group were engaged in the standard program of physical education of the educational and rehabilitation center.

The author's technology of physical and health work for children with complex developmental disorders has been realized during the pedagogical experiment and included the following components: methodological component; organizational and activity component; evaluation component.

The aforementioned components of the implementation of physical and health work are interconnected and have their meaningful and functional purpose: the methodological component reflects the methodological approaches and principles on which the system of health and fitness work has been built; organizational and activity component reveals structure, content, forms, means and methods; assessment component reflects implementation of systematic monitoring and control over the physical, functional and psycho-emotional state of the child and determining the effectiveness of developed technology.

Physical and health work for children with complex developmental disorders has been planned taking into account the peculiarities of the organization of the day regime in the educational and rehabilitation center with other wellness measures and has been built in accordance with methodological approaches that reflect the content and essence of the experimental work: activity-personal, systemic, cultural, health-saving; personality-oriented.

The activity-personal approach has been reflected in taking into account the sensitive periods of development of pupils, the selection of appropriate means and methods of teaching and upbringing of the child.

To ensure physical, mental, social development of the child it should be provided a systematic approach to the harmonious formation of all components of health; physical and psychological preparation for active life and professional activity should be improved on the principles that ensure the health orientation and individuality of approaches; various forms of physical activity and other means of physical improvement might be used.

The use of the cultural approach in the pedagogical experiment made it possible to consider children with complex developmental disorders in the system of physical culture and health work as subjects of physical culture, whose activities are aimed at preserving existing health, preventing deterioration of health and physical and mental fatigue, confidence.

The implementation of the healthsaving approach envisaged the organization of rational motor activity during the day, the implementation of 
health-saving technologies in the educational process; participation in extracurricular sports, cultural and educational activities, during which comprehensive development of a child with complex developmental disorders occurs.

A person-centered approach took into account the individual characteristics of child while creating the necessary conditions for maintaining physical, mental, social health, as well as training and education facilities that would increase the somatic health reserve of children with complex developmental disorders.

During the pedagogical research in the organization of experimental work for children with complex developmental disorders, the principles of individualization, differentiation, productive personality development, continuity and consistency, situational learning, educational reflection have been implemented.

The use of physical and health programs included a rational combination of exercises of different directions; adherence to their optimal intensity and duration of performance in accordance with the individual characteristics of the child with complex developmental disorders, starting position, comorbidities and factor structure of the overall level of physical health. Important structural components of the content of physical and health programs for children with complex developmental disabilities were duration of exercise, intensity of physical activity, differentiation of means.

At the formative stage of the experiment, the children of the experimental group tested the physical training and health program, which included a rational combination of exercises of different directions; observance of their optimum intensity and duration of performance according to individual features of the child with complex developmental disorders; starting position; comorbidities and factor structure of the general level of physical health of a child. Children of the control group were engaged in the standard program of physical education of the educational and rehabilitation center.

The implementation of the physical culture and health program was carried out during the year and provided for the use of three consecutive periods: preparatory, training and support with the allocation of certain funds for the implementation of the tasks.

Important structural components of the content of the developed physical culture and health program for children of primary school age were the duration of classes, the intensity of physical activity, the differentiation of means. According to each stage of the physical training and health program, depending on the level of physical health of a child with complex developmental disorders, the duration and intensity of physical activity was different. The block diagram of the structure according to the content of the fitness program is presented in Figure 1.

For children of primary school age with a low level of physical health the session duration was 20-25 minutes at the preparatory period, at training - 3540 minutes, at maintenance - 50-55 minutes; the intensity of physical activity was $40-45 \%$ and $45-50 \%$ of the heart rate reserve, respectively.

For children with below-average level of physical health duration was 25-30 minutes at the preparatory period of physical training and health program, at training - 30-45 minutes, at maintenance - 55-60 minutes; exercise intensity was $45-50 \%, 50-55 \%$, and 55$60 \%$ of the heart rate reserve, respectively. Children with average level of physical health were engaged for 2335 minutes at the preparatory period, at training - 45-50 minutes, at maintenance - 60 minutes; the intensity of physical activity in the respective periods was $45-50 \%, 55-60 \%$ and $60-$ $70 \%$ of the heart rate reserve. 

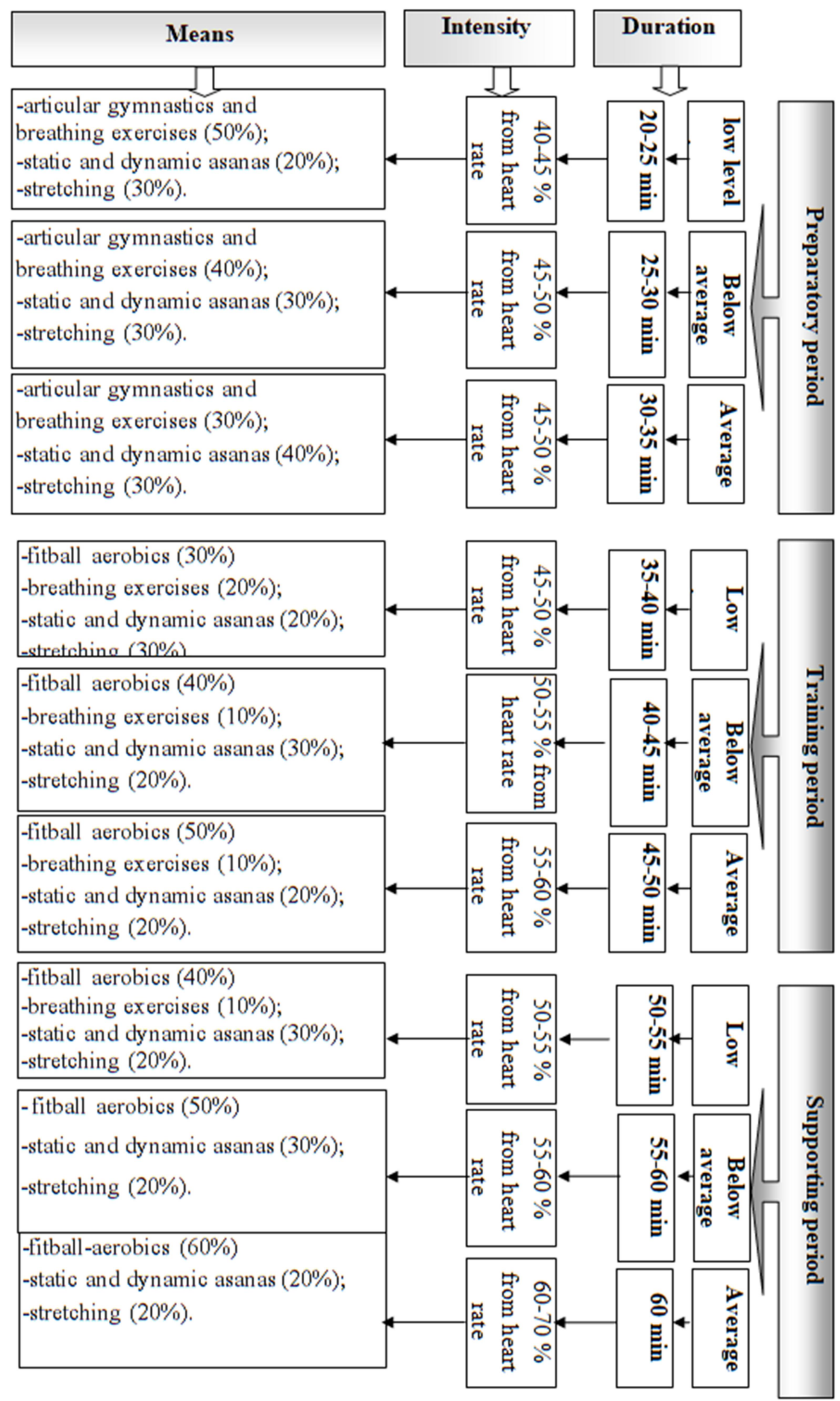

Fig. 1. The structure and content of physical culture and health program for children of primary school age 
Increasing the number of repetitions of a particular exercise occurred gradually as the level of physical fitness of a child with complex developmental disorders.

Taking into account the factor analysis and highlighting the most important indicators that determine the level of physical health of primary school children, the ratio of funds in the fitness program was as follows: $45 \%$ were exercises aimed at improving the functional state of the cardiovascular and respiratory systems; $35 \%$ - to increase strength and speed-motor skills, $20 \%-$ to improve flexibility and coordination. During the pedagogical experiment in the group of girls 7-8 years and 9-10 years of the experimental and control groups (Table 1) body length and body weight increased, but the changes were insignificant $(p>0.05)$.

Changes in anthropometric indicators in girls of primary school age of the experimental and control groups with complex developmental disorders during the pedagogical experiment $(n=53)$

\begin{tabular}{|c|c|c|c|c|c|c|c|}
\hline \multirow[b]{2}{*}{ Indicator } & \multirow[b]{2}{*}{ Groups } & \multicolumn{3}{|c|}{$7-8$ years $(E G=13, C G=12)$} & \multicolumn{3}{|c|}{ 9-10 years $(E G=14, C G=14)$} \\
\hline & & $\begin{array}{c}\text { Before } \\
\text { the study }\end{array}$ & $\begin{array}{l}\text { After the } \\
\text { study }\end{array}$ & $\mathbf{P}$ & $\begin{array}{l}\text { Before the } \\
\text { study }\end{array}$ & $\begin{array}{c}\text { After the } \\
\text { study }\end{array}$ & $\mathbf{P}$ \\
\hline \multirow{2}{*}{$\begin{array}{c}\text { Body } \\
\text { length }(\mathrm{m})\end{array}$} & EG & 6 & 6 & 5 & 1, & 07 & $>0$ \\
\hline & CG & 1,21 & 1,2 & $>0,05$ & 1,2 & 0,06 & $>0,05$ \\
\hline \multirow{2}{*}{$\begin{array}{c}\text { Body } \\
\text { weight } \\
(\mathrm{kg})\end{array}$} & EG & 21,1 & 24 , & $>0,05$ & 26,1 & 1,32 & $>0,05$ \\
\hline & CG & $21,22 \pm 1,34$ & $22,22 \pm 1,24$ & $>0,05$ & $26,20 \pm 1,34$ & $27,10 \pm 1,31$ & $>0,05$ \\
\hline \multirow{2}{*}{$\begin{array}{c}\text { Chest } \\
\text { circumfer } \\
\text { ence }(\mathrm{cm})\end{array}$} & EG & $62,11 \pm 0,40$ & $64,87 \pm 0,40^{* *}$ & $<0,01$ & $65,32 \pm 0,45$ & $67,84 \pm 0,45^{*}$ & $<0,01$ \\
\hline & $\mathrm{CG}$ & $62,21 \pm 0,35$ & $63,21 \pm 0,35$ & $>0,05$ & $65,43 \pm 0,50$ & $66,43 \pm 0,50$ & $>0,05$ \\
\hline
\end{tabular}

Note: * $-\mathrm{p}<0.05 ; * *-\mathrm{p}<0.01$ when comparing the indicators between the experimental and control group at the end of the pedagogical study

Chest circumference in the EG of girls 7-8 years significantly increased by $2.76 \mathrm{~cm}(\mathrm{p}<0.01)$, in $9-10$ years - by $2.52 \mathrm{~cm}(\mathrm{p}<0.01)$, which indicated the development of muscles involved in the act of breathing, as well as the chest.

In girls of 7-8 years and 9-10 years of CG, the chest circumference also increased, but the changes were

insignificant. At the end of the
pedagogical study, the value of the chest circumference in the EG of girls $7-8$ years was higher by $1.66 \mathrm{~cm}$ $(\mathrm{p}<0.01)$ compared to $\mathrm{CG}$ girls $7-8$ years; in EG girls aged 9-10 years - by $1.41 \mathrm{~cm}(p<0.05)$ that emphasized the positive effect of the developed technology of physical culture and health work.

The change in indicators of physical development of boys of primary school age is presented in Table 2.

Table 2

Changes in anthropometric parameters in boys of primary school age of the experimental and control groups with complex developmental disorders during the pedagogical experiment $(n=47)$

\begin{tabular}{|c|c|c|c|c|c|c|c|}
\hline \multirow{2}{*}{$\begin{array}{c}\text { Indicat } \\
\text { or }\end{array}$} & \multirow{2}{*}{$\begin{array}{c}\text { Grou } \\
\text { ps }\end{array}$} & \multicolumn{2}{|c|}{$\mathbf{7 - 8}$ years (EG =13, CG=12) } & \multicolumn{2}{|c|}{$\mathbf{9 - 1 0}$ years (EG =14, CG=14) } \\
\cline { 3 - 8 } & & $\begin{array}{c}\text { Before } \\
\text { the study }\end{array}$ & $\begin{array}{c}\text { After the } \\
\text { study }\end{array}$ & $\mathbf{P}$ & $\begin{array}{c}\text { Before } \\
\text { the study }\end{array}$ & $\begin{array}{c}\text { After the } \\
\text { study }\end{array}$ & P \\
\hline $\begin{array}{c}\text { Body } \\
\text { length (m) }\end{array}$ & EG & $1,24 \pm 0,06$ & $1,27 \pm 0,06$ & $>0,05$ & $1,35 \pm 0,07$ & $1,38 \pm 0,07$ & $>0,05$ \\
\cline { 2 - 8 } & CG & $1,25 \pm 0,05$ & $1,26 \pm 0,05$ & $>0,05$ & $1,36 \pm 0,09$ & $1,37 \pm 0,08$ & $>0,05$ \\
\hline
\end{tabular}




\begin{tabular}{|c|c|c|c|c|c|c|c|}
$\begin{array}{c}\text { Body } \\
\text { weight } \\
\text { (kg) }\end{array}$ & EG & $21,81 \pm 1,25$ & $24,99 \pm 1,15$ & $>0,05$ & $27,69 \pm 2,31$ & $29,82 \pm 1,31$ & $>0,05$ \\
\cline { 2 - 8 } & CG & $21,81 \pm 1,25$ & $22,97 \pm 1,41$ & $>0,05$ & $27,34 \pm 1,91$ & $28,14 \pm 1,91$ & $>0,05$ \\
\hline $\begin{array}{c}\text { Chest } \\
\text { circumfer } \\
\text { ence }(\mathrm{cm})\end{array}$ & EG & $62,44 \pm 0,40$ & $65,44 \pm 0,25$ & $<\mathbf{0 , 0 1}$ & $68,40 \pm 0,50$ & $70,98 \pm 0,50$ & $<\mathbf{0 , 0 1}$ \\
\hline
\end{tabular}

Note: * $-\mathrm{p}<0.05 ; * *-\mathrm{p}<0.01, * * *-$ $\mathrm{p}<0.001$, when comparing the indicators between the experimental and control group at the end of the pedagogical study

As it can be seen from the results of Table 2, at the beginning of the observational stage of the study there was no significant difference between EG and CG groups.

In boys of 7-8 years and 9-10 years of EG and CG there were no significant changes in length and body weight during the study. As a result of the study, the circumference of the chest in the EG of boys 7-8 years significantly increased by $3.00 \mathrm{~cm}(\mathrm{p}<0.01), 9-10$ years - by $2.58 \mathrm{~cm} \quad(\mathrm{p}<0.01)$; in $\mathrm{CG}$ of boys - by $0.61 \mathrm{~cm}(\mathrm{p}>0.05)$ and $0.78 \mathrm{~cm}$ $(p>0.05)$ in the respective age groups.

At the end of the pedagogical study, the value of the chest circumference in the EG of boys 7-8 years was higher by $2.30 \mathrm{~cm}(\mathrm{p}<0.001)$ compared to the $\mathrm{CG}$ of boys of 7-8 years; in EG of boys of 910 years - by $1,99 \mathrm{~cm}(\mathrm{p}<0,01)$.

The results of re-testing of wellbeing, activity and mood in girls of primary school age with complex developmental disorders are presented in Table 3. mood of girls of primary school age of the experimental and control groups with complex developmental disorders during the pedagogical experiment $(n=53)$

\begin{tabular}{|c|c|c|c|c|c|c|c|}
\hline \multirow[b]{2}{*}{ Indicator } & \multirow[b]{2}{*}{ Groups } & \multicolumn{3}{|c|}{$7-8$ years $(E G=13, C G=12)$} & \multicolumn{3}{|c|}{ 9-10 years $(E G=14, C G=14)$} \\
\hline & & $\begin{array}{c}\text { Before } \\
\text { the study }\end{array}$ & $\begin{array}{l}\text { After the } \\
\text { study }\end{array}$ & $\mathbf{P}$ & $\begin{array}{l}\text { Before the } \\
\text { study }\end{array}$ & $\begin{array}{l}\text { After the } \\
\text { study }\end{array}$ & $\mathbf{P}$ \\
\hline \multirow{2}{*}{ Well-being } & EG & $3,75 \pm 0,16$ & $4,50 \pm 0,23$ & $<0,05$ & $3,75 \pm 0,20$ & $4,85 \pm 0,22$ & $<0,01$ \\
\hline & CG & $3,55 \pm 0,20$ & $4,10 \pm 0,22$ & $>0,05$ & $3,78 \pm 0,19$ & $3,88 \pm 0,20 * *$ & $>0,05$ \\
\hline \multirow{2}{*}{ Activity } & $\mathrm{EG}$ & $3,42 \pm 0,47$ & $5,80 \pm 0,38$ & $<0,01$ & $4,51 \pm 0,31$ & $6,10 \pm 0,27$ & $<0,01$ \\
\hline & $\mathrm{CG}$ & $3,35 \pm 0,22$ & $3,95 \pm 0,20 * * *$ & $>0,05$ & $4,34 \pm 0,21$ & $4,90 \pm 0,19 * *$ & $>0,05$ \\
\hline \multirow{2}{*}{ Mood } & EG & $3,58 \pm 0,41$ & $6,00 \pm 0,42$ & $<0,01$ & $3,27 \pm 0,35$ & $5,90 \pm 0,33$ & $<0,01$ \\
\hline & $\mathrm{CG}$ & $3,62 \pm 0,36$ & $3,90 \pm 0,20 * * *$ & $>0,05$ & $3,29 \pm 0,25$ & $3,99 \pm 0,21 * * *$ & $>0,05$ \\
\hline
\end{tabular}

Note: ${ }^{*}$-p $<0.05 ;{ }^{* *}-\mathrm{p}<0.01,{ }^{* * *}-\mathrm{p}<0.001$, when comparing the indicators between the experimental and control group at the end of the pedagogical study

During the pedagogical study in girls 7-8 years of EG there was a probable improvement in well-being by 0.75 points $(\mathrm{p}<0.05)$, activity - by 2.38 points $(\mathrm{p}<0.01)$, mood - by 2.42 points $(p<0.01)$; girls aged $9-10$ years - by 1.10 points $(p<0.01), 1.59$ points $(p<0.01)$, 2.63 points $(\mathrm{p}<0.01)$.

In girls 7-8 years of $\mathrm{CG}$ there was only a tendency to improve psychoemotional state, well-being improved by 0.55 points $(p>0.05)$, activity - by 0.60 
points $(p>0.05)$, mood - by 0.28 points $(p>0.05)$; girls aged 9-10 improved by 0.10 points $(\mathrm{p}>0.05), 0.56$ points $(p>0.05), \quad 0.70$ points $\quad(p>0.05)$, respectively.

The examined 7-8 years of EG compared to their CG peers showed significantly higher activity and mood indicators by 1.85 points $(\mathrm{p}<0.01)$ and 2.10 points $(\mathrm{p}<0.01)$, respectively; in girls 9-10 years of EG the state of wellbeing was higher compared to peers CG by 0.97 points $(\mathrm{p}<0.01), 1.20$ points $(\mathrm{p}<0.01)$ and 2.00 points $(\mathrm{p}<0.001)$, respectively.

The results of re-testing of wellbeing, activity and mood in boys of primary school age with complex developmental disorders are presented in table 4.

Table 4

Changes in health, activity and mood in boys of primary school age of the experimental and control groups with complex developmental disorders during the pedagogical experiment $(n=53)$

\begin{tabular}{|c|c|c|c|c|c|c|c|}
\hline \multirow[b]{2}{*}{ Indicator } & \multirow[b]{2}{*}{$\begin{array}{l}\text { Group } \\
\text { s }\end{array}$} & \multicolumn{3}{|c|}{$7-8$ years $(E G=13, C G=12)$} & \multicolumn{3}{|c|}{ 9-10 years $(E G=14, C G=14)$} \\
\hline & & $\begin{array}{l}\text { Before } \\
\text { the } \\
\text { study }\end{array}$ & $\begin{array}{l}\text { After the } \\
\text { study }\end{array}$ & $\mathbf{P}$ & $\begin{array}{l}\text { Before the } \\
\text { study }\end{array}$ & $\begin{array}{l}\text { After the } \\
\text { study }\end{array}$ & $\mathbf{P}$ \\
\hline \multirow{2}{*}{ Well-being } & EG & $3,50 \pm 0,19$ & $4,95 \pm 0,17$ & $<0,01$ & $3,25 \pm 0,26$ & $5,45 \pm 0,21$ & $<0,01$ \\
\hline & $\mathrm{CG}$ & $3,55 \pm 0,20$ & $3,80 \pm 0,22^{* *}$ & $>0,05$ & $3,21 \pm 0,18$ & $3,78 \pm 0,1^{* * *}$ & $>0,05$ \\
\hline \multirow[t]{2}{*}{ Activity } & EG & $3,42 \pm 0,18$ & $5,55 \pm 0,38$ & $<0,01$ & $5,11 \pm 0,38$ & $5,99 \pm 0,21$ & $<0,05$ \\
\hline & $\mathrm{CG}$ & $3,45 \pm 0,18$ & $3,65 \pm 0,27^{* *}$ & $>0,05$ & $5,14 \pm 0,32$ & $5,25 \pm 0,21^{*}$ & $>0,05$ \\
\hline \multirow{2}{*}{ Mood } & EG & $3,27 \pm 0,50$ & $6,11 \pm 0,33$ & $<0,01$ & $5,70 \pm 0,40$ & $6,25 \pm 0,35$ & $>0,05$ \\
\hline & $\mathrm{CG}$ & $3,62 \pm 0,36$ & $3,90 \pm 0,21^{* * *}$ & $>0,05$ & $5,83 \pm 0,24$ & $5,37 \pm 0,27^{*}$ & $>0,05$ \\
\hline
\end{tabular}

Note: * $-\mathrm{p}<0.05 ; * *-\mathrm{p}<0.01, * * * \quad-$ $\mathrm{p}<0.001$, when comparing the indicators between the experimental and control group at the end of the pedagogical study

During the pedagogical study in boys of 7-8 years of EG there was a probable improvement in well-being by 1.15 points $(p<0.01)$, activity - by 1.90 points $(p<0.01)$, mood - by 2.21 points $(\mathrm{p}<0.001)$; boys aged $9-10$ improved by 2.20 points $(\mathrm{p}<0.001)$ and activity by 0.88 points $(\mathrm{p}<0.05)$.

Boys of 7-8 years old with complex disorders of EG showed significantly better well-being by 1.15 points $(\mathrm{p}<0.01)$, activity - by 1.90 points $(\mathrm{p}<0.001)$ and mood - by 2.21 points $<0.001$ ) compared with CG peers at the end of the pedagogical experiment; 9-10 years - by 1.67 points $(\mathrm{p}<0.001), 0.74$ points $(p<0.05), 0.88$ points $(p<0.05)$.

Conclusions and research perspectives. It was found that girls and boys with complex developmental disorders during the pedagogical study probably improved indicators of physical development and psychoemotional state. Girls of 7-8 years of EG compared to their CG peers showed significantly higher activity and mood indicators by 1.85 points and 2.10 points, respectively; in girls 9-10 years of EG the state of well-being was higher compared to peers CG by 0.97 points, 1.20 points and 2.00 points, respectively. Boys of 7-8 years of EG showed significantly better well-being by 1.15 points, activity - by 1.90 points and mood - by 2.21 points compared with CG peers at the end of the study; 9-10 years - by 1.67 points, 0.74 points, 0.88 points, respectively.

Prospects for further research will be aimed at substantiating the technology of physical culture and health work for children with complex developmental 
disorders in the educational and rehabilitation center.

\section{REFERENCES (TRANSLATED \& TRANSLITERATED)}

1. Bondar, V.I. (2005). Problemy korektsiinoho navchannia u spetsialnii pedahohitsi [Problems of correctional education in special pedagogy]: navch. posib. Kyiv [in Ukrainian].

2. Hlushenko, K.O. \& Hladkykh, N.V. (2014). Aktualni problemy navchannia ta vykhovannia ditei $z$ kompleksnymy porushenniamy rozvytku $\mathrm{v}$ Ukraini [Current problems of education and upbringing of children with complex developmental disorders in Ukraine]. Naukovyi chasopys NPU imeni M.P. Drahomanova. Seriia 19: Korektsiina pedahohika ta spetsialna psykholohiia - Scientific journal of NPU named after M.P. Drahomanov. Series 19: Correctional pedagogy and special psychology, 26, 52-57 [in Ukrainian].

3. Dzhurynskyi, P.B.

(2003).

Fizychna reabilitatsiia ditei zi skoliotychnymy vadamy khrebta $\mathrm{v}$ systemi navchalno-ozdorovchoi roboty shkoly-internatu [Physical rehabilitation of children with scoliotic defects of the spine in the system of educational and health work of the boarding school]. Extended abstract of Candidate's thesis. Odesa [in Ukrainian].

4. Kobylchenko, V.V.

Teoretyko-metodychni

(2010). zasady psykholohichnoho suprovodu pidlitkiv $z$ hlybokymy porushenniamy zoru [Theoretical and methodological principles of psychological support of adolescents with profound visual impairments]. Extended abstract of Doctor's thesis. Kyiv [in Ukrainian].

5. Kolupaieva, A.A.

(2007).

Pedahohichni osnovy intehruvannia shkoliariv $z$ osoblyvostiamy psykhofizychnoho rozvytku u zahalnoosvitni navchalni zaklady [Pedagogical bases of integration of schoolboys with features of psychophysical development in general educational institutions]: monohrafiia. Kyiv [in Ukrainian].

6. Kulbida, S.V. (2010). Teoretykometodychni zasady vykorystannia zhestovoi movy $u$ navchanni nechuiuchykh [Theoretical and methodological principles of using sign language in teaching deaf people]: monohrafiia. Kyiv: Poliprom [in Ukrainian].

7. Leshchii, N.P. (2019). Vmotyvuvannia ditei zi skladnymy porushenniamy rozvytku do fizkulturno-ozdorovchykh zaniat v osvitno-reabilitatsiinykh tsentrakh [Motivation of children with complex developmental disabilities to exercise classes in educational and rehabilitation centers]. Colloquiumjournal, 16(40), 26-29. [in Ukrainian].

8. Leshchii, N.P.

(2019).

Orhanizatsiia kompleksnoho medykopsykholoho-pedahohichnoho

suprovodu ditei zi skladnymy porushenniamy rozvytku $\mathrm{v}$ protsesi fizkulturno-ozdorovchoi roboty $\mathrm{v}$ osvitno-reabilitatsiinomu tsentri [Organization of complex medical and psychological support of children with complex developmental disorders in the process of physical and health work in the educational and rehabilitation center]. Sciences of Europe, 41(3), 50-53 [in Ukrainian].

9. Liakhova, I.M. (2006). Teoretykometodychni osnovy korektsii rukhovoi sfery ditei zi znyzhenym slukhom zasobamy fizychnoho vykhovannia [Theoretical and methodological bases of correction of the motor sphere of children with hearing impaired means of physical education]. Extended abstract of Doctor's thesis. Kyiv [in Ukrainian].

10. Sirotkina, T.V.

(2015). Orhanizatsiino-pedahohichni umovy korektsii fizychnoho rozvytku slabozorykh uchniv pochatkovoi shkoly [Organizational and pedagogical conditions for the correction of physical development of visually impaired 
primary school students]. Extended abstract of Candidate's thesis. Kyiv [in Ukrainian].

11. Suprun, M.O., Vysotska, A.V., \& Hladchenko, I.V. (2014). Sotsializatsiia dytyny $z$ obmezhenymy rozumovymy mozhlyvostiamy $v \quad$ suchasnomu osvitnomu vymiri [Socialization of a child with mental disabilities in the modern educational dimension]: navch.-metod. posib. Kyiv: Instytut spetsialnoi pedahohiky NAPN Ukrainy [in Ukrainian].
Received: July 08, 2020 Accepted: August 04, 2020 